特集・II

\title{
分離機能性繊維としての 活性炭素繊維の利用
}

\section{1.はじめに}

繊維のもつ機能は大きく 3 つに分けられる。1つはそ の形態のため, 単位重量あたりの表面積が非常に広いこ と，2つに加工忙に富み，系，織物，編物，紙などと各 種の形態のあのへと加工するととが容易であるとと， 3 つに緎維軸方向に非常に高い強度をもつととである。従 来功使用されている材料を織維状にすれば, 上記の特 性を付与した新しい機能をむつ材料としての再生が可能 であろうと考えられる。

物質の分離, 特に希薄系においては従来より活性炭が 各方面で使用されている。その使用量は国内で年間 5 万 $^{1)}$ トン強, そのはとんどが粉状と粒状である。とのよう な活性炭を㵶維状にすると上記の少なくとも2つの長所 が引き出される。1つは加工性であり, 各種の形態に加工 できれば使用領域或いは使用方法が異なり，新しい商品 展開が可能になる。又むう1つはその広い表面積を有効 に利用できるため, 活性炭のもつ最大の機能, 吸着性を より高めることである。例えば拡散速度を考える場合， $100 \times ッ シ ュ の$ 粉末活性炭の粒径は約 $150 \mu$ であり, 通 常の織維で $20 \mu$ 程度の物をつくることは非常に容易であ るととから, 吸着速度の一要因である拡散速度を非常に 高めることが期待できる。又表面積が増えるととにより 当然吸着の場む広からり，吸着容量を增やすととにあなる。 本稿では, 分離機能性繊維として活性炭素㵶維をとり 上げ，その性質と利用状況について紹介したい。活性炭 素繊維は実用強度をむつものとして世界で初めて東洋紡 績により開発されたが，その後国内では東邦ベスロン， クラレケミカルにより出発原料を異にした製品が市場に あらわれ, 各方面で使用されている。活性炭素繊維の国 内での生産量は発表されていないため不明であるが, 年 間 100 トン前後とみられ，活性炭のそれと比較すれば今

Use of Activated Carbon Fiber with High Performance for Separation

SUSUMU OHMORI

TOYOBO CO., LTD. Research Center. 東洋紡績株式会社 総合研究所 主席研究員

\section{大 森進}

だ貮々たるものである。しかし活性炭にはない機能或い はより優れた機能の活用が進めば，その生産量も飛躍的 に伸びるものと推測され, 粉末活性炭, 粒状活性炭につ つく第 3 の活性炭として位置つけられる日も近い。

国内 3 社で生産されている活性炭素緎維の出発原料は セルロース繊維, アクリル纎維, フェノール䋐維である が, その特性はほぼ似かよっており，今回はセルロース 擮維からえられた活性炭素繊維を中心に話をしたい。

\section{2. 活性炭素䋐維の特徴}

\section{1 形 態}

活性炭素緎維之粒状活性炭の顕微鏡写真 ${ }^{2}{ }^{2}$ を図 1, 図 2, 図 3 に示す。図 1 は活性炭素繊維の形態を示し, 困 2 はその表面の拡大図である。これらから分かるように， 活性炭素繊維は非常に滑らかな表面をもつ絨維状物であ る。これに反して, 図3で示されるように, 粒状活性炭 は凹凸がはげしく，各種のオーダーをむつ穴の集合して いることが分かる。これを細孔径分布曲線で見たのが図 4 である。活性炭素繊維は $10 \AA 20 \AA 020$ のたりに鋭い単 一のピークをもっている。乙れはいずれの活性炭素緎維 にも共通であり，ての単一の鋭いミクロポアーが分子の 吸着に非常に威力を発揮するととになる。特にガス系に おいては活性炭より優れた吸着能を示す。粒状活性炭は 四から分加るように, マクロポアー,トランジショナル

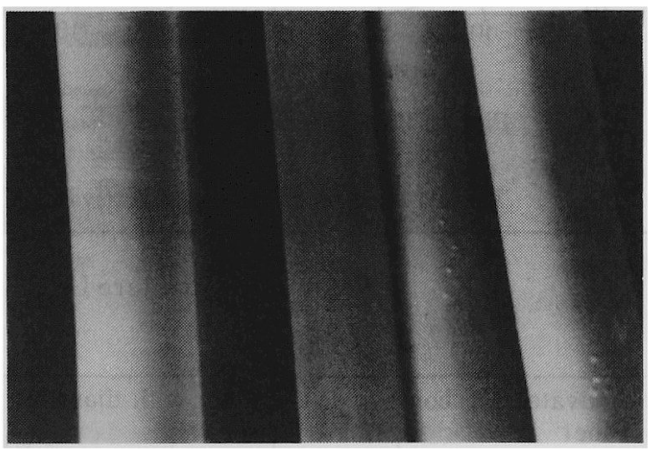

Fig. 1 Electron micrograph of activated carbon fiber $(x 1200)$ 


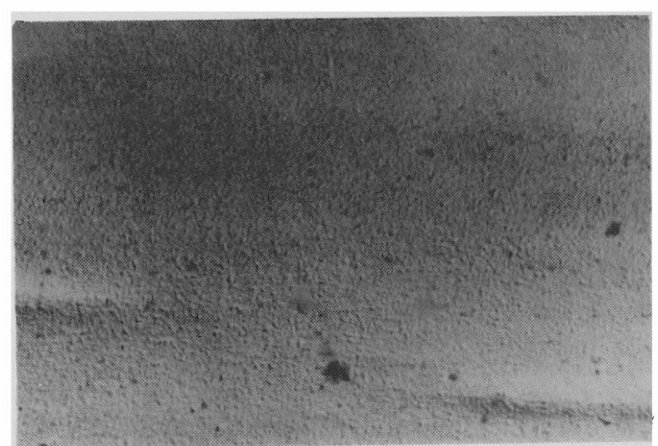

Fig. 2 Electron micrograph of activated carbon fiber $(x 9000)$

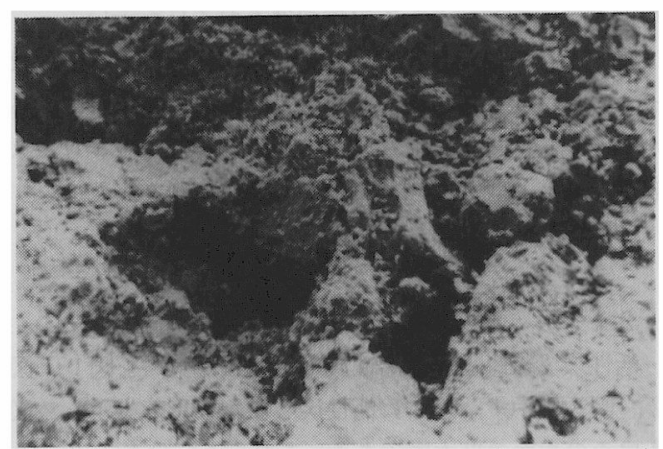

Fig. 3 Electron micrograph of granular activated carbon $(\times 1200)$

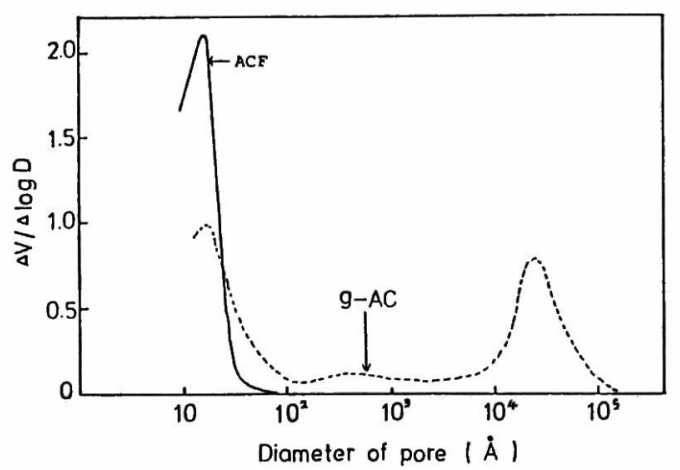

Fig. 4 Pore size distribution
ポアー,ミクロポアーと各種の穴を所有しており，幅広 い吸着に適していると言える。表 1 は典型的な活性炭素 䋐維之粒状活性炭の形態特性の比較である。活性炭素緎

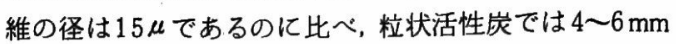
であり，ガス分子の拡散速度に大きな差がでるであろう 之推測できる。又細孔表面積む活性炭素瀻維の方が広く, 吸着容量が大きいと言える。しかしながら，かさ密度の 比較では活性炭素瀻維は粒状活性炭より一析小さく，単 純に量だけで勝負する場合には一工夫が必要であると言 える。

\section{2 吸脱着性能}

図 5 はトルエンを吸着させた時の破過曲線 ${ }^{8)}$ を示した あのである。わずか $4 \mathrm{~mm}$ の厚みの活性炭素瀻維層が破 過されるまで完全にトルエンを吸着していることがわか る。又この曲線加ら計算される吸着帯厚みも非常に短 く, 吸着速度が非常に速いてとを証明している。図6は 同じくトルエンにおいて吸着と脱着を示したものである。 粒状活性炭に比へて極めて速い速度で吸脱着のおてなわ れることがわかる。このように極めて速い吸脱着速度は 既に述へた拡散速度の項が大きく効いていると思われる。

\section{3 加工性}

市販の活性炭素纎維は大きくわけると次のような製品

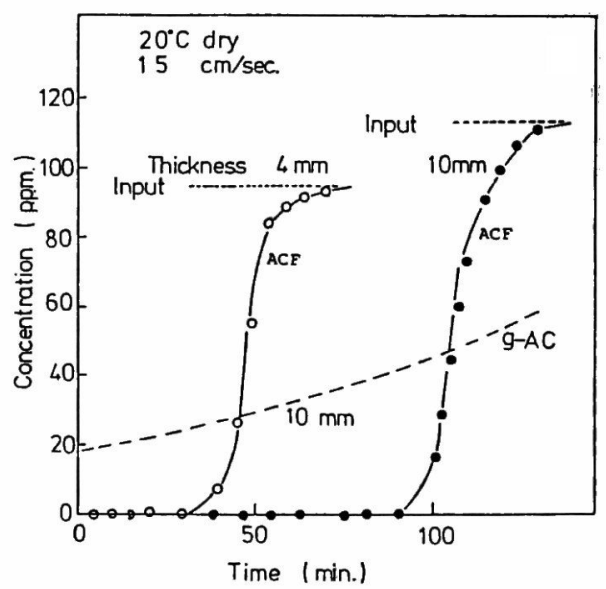

Fig. 5 Breaking curves for Toluene

Table 1 Characteristics of Activated Carbon Fiber and Granular Activated Carbon

\begin{tabular}{|l|l|l|c|c|c|c|c|}
\hline & Form & Structure Unit & $\begin{array}{l}\text { Area } \\
\text { Density } \\
\mathrm{g} / \mathrm{m}^{2}\end{array}$ & $\begin{array}{l}\text { Apparent } \\
\text { Density } \\
\mathrm{g} / \mathrm{cm}^{3}\end{array}$ & $\begin{array}{l}\text { Outer } \\
\text { Surface } \\
\text { Area } \\
\mathrm{m}^{2} / \mathrm{g}\end{array}$ & $\begin{array}{l}\text { BET } \\
\text { Surface } \\
\text { Area } \\
\mathrm{m}^{2} / \mathrm{g}\end{array}$ & $\begin{array}{l}\text { Micro Pore } \\
\text { Diameter } \\
\mathrm{A}\end{array}$ \\
\hline $\begin{array}{l}\text { Activated Carbon } \\
\text { Fiber }\end{array}$ & Felt & $\begin{array}{l}\text { Fiber with diameter } \\
\text { of } 15 \mu\end{array}$ & 200 & 0.05 & $\sim 0.2$ & 1500 & 14 \\
\hline Activated Carbon & Granule & $\begin{array}{l}\text { Granule with diameter } \\
\text { of } 4 \sim 6 \mathrm{~mm}\end{array}$ & - & $0.40 \sim 0.50$ & $\sim 0.001$ & 900 & 26 \\
\hline
\end{tabular}




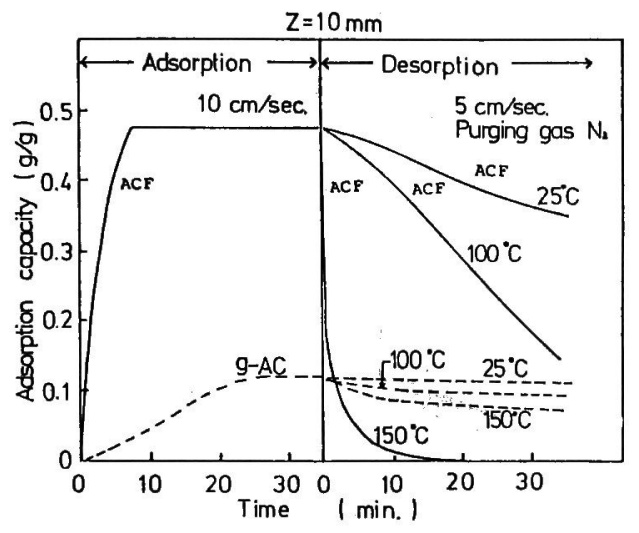

Fig. 6 Adsorption and desorption properties for Toluene

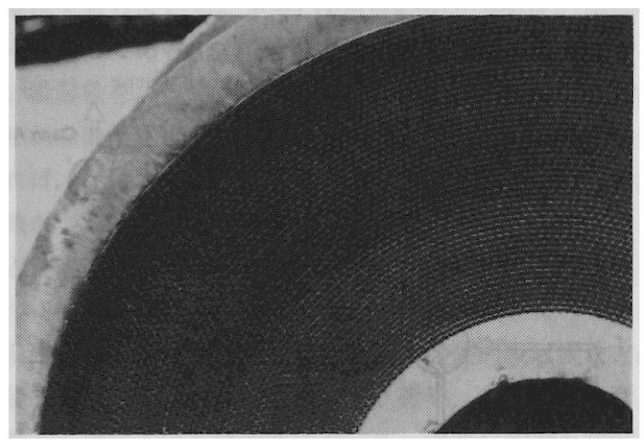

Fig. 7 Surface of honeycomb rotor
形状をもっている。ファイバー状，フェルト状，クロス 状(編織物)，ペーパー状，そしてペーパーを加工した八 二カム状である。てのように2 次元的或いは 3 次元的広 がりをむたすととは使用方法にバラエティーをもたらす のみならず，活性炭素瀻維のもつ優れた性能を生かすこ とにあなる。すなわちバインダーを使うことなく 3 次元 構造がえられるととは所有する性能を殺すととなく使え るととを意味する。上記形態の内, ベーパーのみはパル プとの混抄品であり，その意味で活性炭素瀻維 $100 \%$ で はないが，紻維状であるため 70〜80\%の混率でぺーパー 加工が可能であり, 性能の低下は少ない。困7 はペーパ 一を使用して作ったハ二カム構造体であり，吸着剂任対 して平行に風を流して吸着を行う方法は従来には考えら れなかった方法である。

\section{3. 活性宸素緎維の利用状況}

活性炭素織維はその最大の機能である吸着作用を使っ て分離分野に利用されることが主体である。しかし最近 その広い表面皘を反応場として利用する用途がひらけ， 電子部品への参入も今後の大きな用途の 1 つと予測され ている。以下個々の商品について少し触れたい。

\section{1 溶剤回収装置}

第 1 次オイルショック以後の石油の值上りにより，従 来大気中に放散されていた溶剂類を回収して再使用する ととが考えられた。それまでの溶剤回収装置には粒状活 性炭を充填させた槽が使用されていたが，粒状活性炭の 代りに活性炭素緎維を使うことにより，数々の特長が生

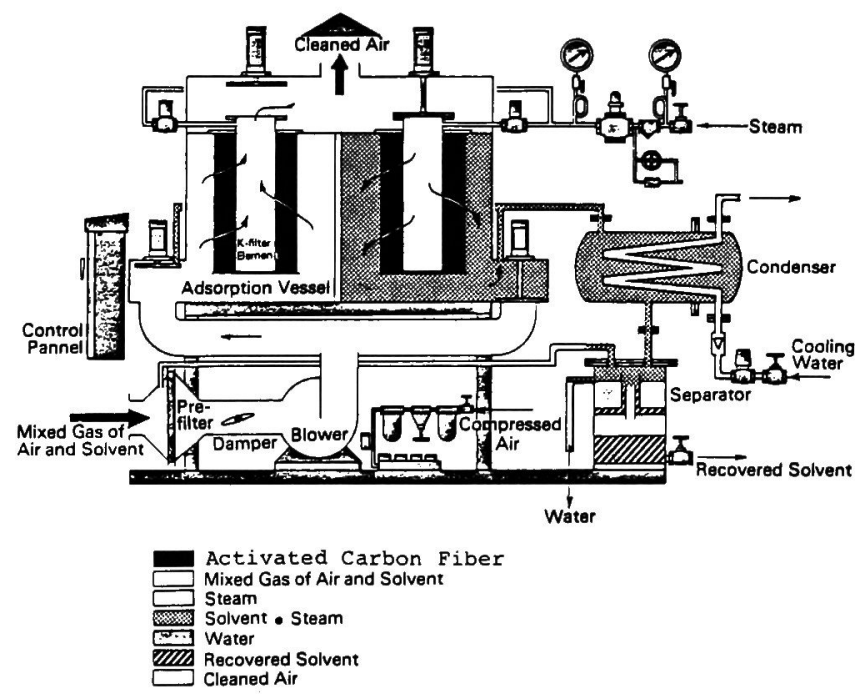

Fig. 8 Schematic representation of solvent recovery apparatus with activated carbon fiber 
まれ，活性炭素緎維を使う商品としては最初の成功をお

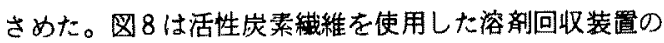
概略图であり，フェルト状の活性炭菜㵶䧽が巻かれたシ リンダー状の吸着エレメントが使用されている。基本的 な原理は精状活性炭の装置と変りないか，次の上うな特 長を有している。

（1）回収した溶剂の品質がすぐれており，分解しやす い溶阂の回収にも適している。

（2）高沸点をむつ溶郕や重合性モノマーを含む溶郕に も適応でき，吸著剂の寿命が長く，適用籍围が広い。

（3）吸着効率が高いため，溶剂の回収率が高い。

（4）吸着熱などの発熱がなく，安全性が高い。

（5）裝置が軽量コンパクトである。

上記の特長は活性炭素瀻維のむつ優れた吸脱着性能のた め生じたものである。特に速い吸脱着速度は上記 (1) (2) (3)の特長を生む要因になっている。又欠点として 考えられた低いかさ密度は吸脱着の繰返しサイクルを短 くすることにより克服されてむりり，短くすることが可能 になったのあ吸脱着速度が速いからである。

活性炭素紻維を使用した溶成回収装置は回収装置の市 場では後発商品であるが, 現在では既に主力となりつつ ある商品に育ったと言える。当初，金属の脱脂洗浄工程 からの溶剂回収が主体であったが，現在はあらゆる分野 での排出溶昘の回収に使用されており，特に最近では， 半導体の洗浄工程からでる溶剤回収が増えてきている。 エレクトロニクス分野の発展がこの分野にあ及んできて いると言える。

\section{2 平行流型吸脱羙装置}

炭化水素類は大気污染防止の面からその排出が規制さ れているか，低藵度ゆえ今だに放任されている排出源が 多い。特に低濃度大風量の排ガス源に対して，対策が望 まれながら適当な装置が存在しなかったと言える。平行 流型吸脱着装置はこれらの点を考虑して考案された新し いタイプの吸脱着装㯰である。図9はこの装置の心脿部 であり，吸脱着をおこなうローターを示している゙。こ のローターは活性炭素織維から作られたペーパーをハ二 力ム状に巻き上げたものであり，好理すべき風は吸着剤 に対して平行に流される。ロータ一は毎時数回転の割合 で回転しており，外部シールにより区割された脱着部に おいて，加熱空気により脱着がおてなわれる。脱着ガス は濃度風量共に濃縮されて排出される。すなわち脱着風 量は吸着風量の10 分の1 加数 10 分の1になり, 脱着 濃度は吸着濃度の 10 倍から数 10 倍になる。この濃縮さ れだガスを通常の処理装置(溶剤回収装置，触媒酸化装 㯰など)で好理してやれば，システム全体として小型化 及び低コスト化が可能になる上言うものである。このよ
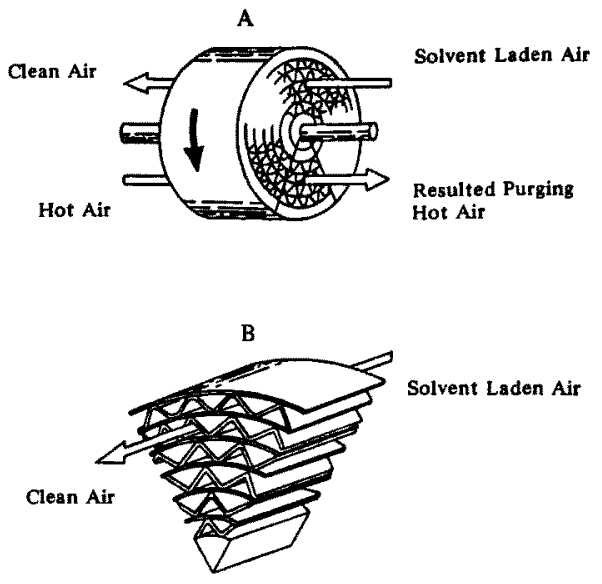

Fig. 9 Schematic representation of honeycomb rotor with parallel flow

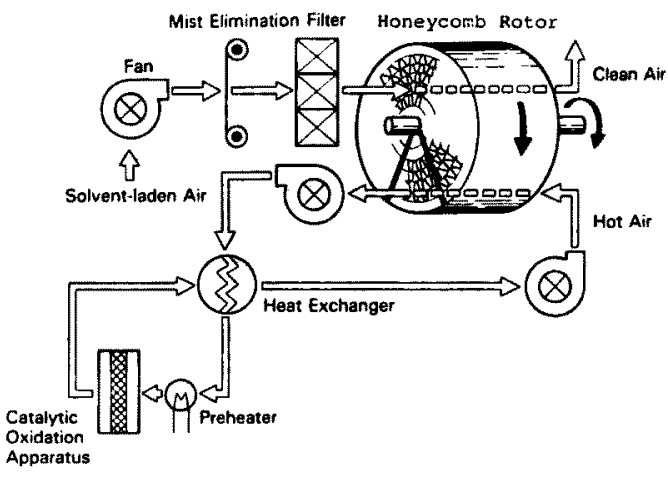

Fig. 10 System of honeycomb rotor combined with catalytic oxidation apparatus

うに平行流财着をおこなうことは压力損失の面から吸着 風速を大幅に高くするととを可能にしており，速い吸着 風速にもかかわらず良い吸着性能を維持できるのす吸看 速度の速い活性炭菜瀻維を使用しているととに寄因して いる。大風量を姏理するための最大の要因はコストとサ イズであり，従来の吸着装置に比へて，4〜6倍も高い 風速によるサイズの小型化と漊絤寸るととによるコスト の低下が可能になった。四10は触媒酸化装置との組合わ せシステムであり，触媒酸化装置ては濃縮されたガスの 酸化熱により，自然すら可能であり，大幅なコストダウン が可能である。固定発生源より排出される炭化水素の約 50\%は泾装ブースからの排出であり，特に低婊度ながら 莫大な量を排出している自動車生産ラインは何らかの対 策が必要になっている。国内での奏精にふまえて海外に おいても今後活発な展開があるものと予想されている。 


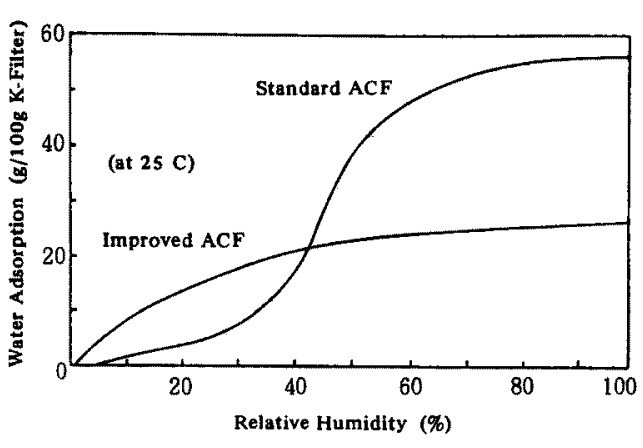

Fig. 11 Adsorption isotherms of activated carbon fiber

\section{3 除湿機}

活性炭素䄉維は炭化水素類の吸着に加えて，優れた吸 湿性をるっている。図11 は相対湿度之吸湿量の関係を みたものである い吸湿性を，改良タイプで低湿度側で高い吸湿性を示す。 これらの活性炭素織維で上記の平行流型吸脱着装置を作 れば，炭化水素の代りに水分の吸着惯縮除去を行う除湿 機かつくれる。この蓄置は吸着除湿のため，低温低湿ほ ど性能が発揮でき，容易にー30 Cからー40 Cの露点をむ つ空気がららる。さらに塩化リチウムやアスべストを 使用していないという特舆も兼格，従来の吸収式などの 装置に比へて優れた性能となる。近年，医薬，生化学， 電子工業などの各種産業において，清浄な乾いた空気の 必要性が高まっており，この装置の需要が伸びている。

\section{4 オソンフィルター}

静電式複写機の生産金額は昭和 50 年に 1000 億円，昭 和 59 年に 5000 億円(予想 $)^{6)}$ 之非常に大きな市場一之発 展している。てれら静電式複写機は高電圧を使用するた め，オゾンを発生し，その除去装置を内蔵するととが必 要とされている。事務機器の軽薄短小化は複写機向同じ でフフィルターを内蔵する場所が限られてきている。薄 く，軽く，小さい〉ィルターが望まれている。活性炭素 饿維のペーパーによるハニカム構造体は成型の自由さ， 軽さ，オソン分解能の良さで各社の複写㙨に採用され， その分野の主体になりつつある。図 12 は厚さ $4 \mathrm{~cm}$ と2

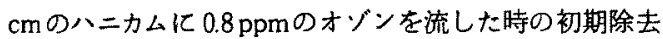
率である。風速 $1 \mathrm{~m} / \mathrm{sec}$. で除去率 $95 \%$ を示す厚さ $2 \mathrm{~cm}$ の八ニカムは压損がわずか $1.5 \mathrm{~mm} \mathrm{H}_{2} \mathrm{O}$ と非常に小さく， 装置内で容易に装埴される。風を流す断面む大きさを自 由に変ることができ，好評をえている。複写機之共に成 長したオソンフィルターむ今後, ファクシミリ，プリン ターなどへの装着が考えられており，今後の成長か期待 されている。

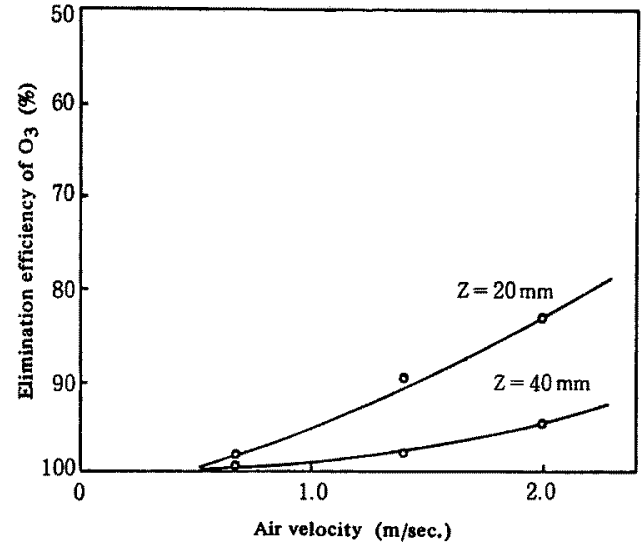

Fig. 12 Elimination efficiency of $\mathrm{O}_{3}$ by honeycomb of activated carbon fiber. Concentration: $0.8 \mathrm{ppm}, 20^{\circ} \mathrm{C}$, RH50\%

\section{5 その他}

活性炭素䄉維のもつ传れた吸着能を利用して，各種の 分野で色々な商品に応用されている。

\section{(1) マスク類}

簡易マスクとして，産業用，医療用，農業用に利用さ れている。容易に加工でき，軽量で高性能である。又防 毒マスクや放射性ガス用のマスクにも適用されている。

\section{(2) 空気清浄機用脱臭フィルター}

家庭用、業務用，自動車用と主としてタ心゙コ臭をとる ために使用されている。軽量で高性能である。

(3) ガソリン蒸散防止フィルター

自動車のガソリンタンクなどから自動車停止時に排出 してくるガソリンを吸着し，走行時脱着してもとへもど すフィルターで, 軽量高性能である。

\section{(4) 鮮度保持材}

野菜，果物などの鮮度を伸す吸着剂でペーパーなどに して包む方法で使用されている。軽量で取扱いが容易な 特長がある。

\section{(5)一般脱臭剠}

靴の中敷き，医療用パッド，冷蔵庫用，生理ナプキン， 净水器など。

\section{4. 今後の動问}

活性炭素絨維のもつ広い表面積を吸着以外江電気化学 反応の場として利用する分野が開けている。電池及び電 気二重層コンデンサー(キャパシター) 用の電極材である。 これは炭妻のbつ特微, 導電性, 電気化学的不活性, 耐 薬品性といった特徵之上記の広い表面積をもつという性 質が組合わさった結果，展開が可能になった分野である。 今後, 活性炭素䋞維の大きな柱になる分野と思われる。 
電気二重層コンデンサーは活性炭素䋐維電極 ${ }^{7)}$ 上有機電 解液の界面に生ずる電気二重層を利用して，電荷を蓄棈 するもので既に従来のアルミ電解コンデンサーの数千倍 あの静笔容量をもつものが市販されている。優れた充放 電特性から，メモリーのバックアップ電源として使用さ れ，その市場規模む大幅伸びている。この上うに活性 炭素䋊維を吸着以外の分野汇展開しようとする動きは今 後ますます盛んになると思われる。

纎維の使用の最大手は衣服である。その意味から，活 性炭素縕維を使用した衣服への展開が考えられている。

化学防護衣などであり，農薬などの有毒物から人体を守 るための衣服である。活性炭素䋐維の強度向上と共にと の分野への展開も大きくなるであろう。

活性炭素紻維は従来の活性炭にはない優れた特性をも っているが, 反面価格加高いという久点をもっている。 活性炭素䋐維の歴史牥高価格を吸収できる商品開発の歴
史であった。今後生産量拡大による低コスト化す考えら れるが，上り一層の高付加価值商品の開発が待たれる。

\section{参考文献}

1) 化学工業年鑑, 昭和 58 年版, 233

2）福田卓司，木幡眺雄，松尾達樹，化学工業， 40 . No. 5, 257 (1976)

3）大森 進, 木幡輝雄, 福田卓司, 石崎信男, 駒形秀 樹, 化学工業, 44, No, 6, 343(1980)

4) 大森 進, 松尾達樹, 前川禎佑, 化学装置, 20 , No. 10, 65 (1978)

5）稲村成一，今村嘉男，岸元武士，大東照夫，駒形秀 樹, 島田将慶, 一力弘司, ケミカル・エンシニアリ ング, 28, №.8, 575(1983)

6）機械統計月報, 1984

7) 日経産業新聞，58 年 9 月 13 日

(昭和 60 年 3 月 15 日受理)

\section{会告原稿について}

講演会、研究会、見学会、そのほかの催し物についてのおしらせを本誌に揭載希望される 場合は，発行の前月15日までに学会事務局へお届け下さい。

期日を過ぎて到着した分については次号揭載となります。

原稿用紙 ( $コ コ 25 \times タ テ 16 \cdots 400$ 字詰) へ楷書で丁寧に，つぎの要領で書いて下さい。 なお誌面の都合で要約または，その採否につきましては広報委員会に御一任願います。また 会告は会員各位へ情報伝達および相互の連絡を密にする目的で積極的に行いますのでお含み おき下さい。
1. 大タイトル
2. 主旨があれば简潔に
3. 主催, 共催, 協蕒など
4. 開催日時 (曜日も)
5. 会場 (詳細化, 電話も)
6. 講演募集またはプログラム
7. そのほか要点执よび連絡先（電話）

広報委員会 